\title{
HIGH LEVEL OF COPPER APPLICATION TO SOIL AND LEAVES REDUCE THE GROWTH AND YIELD OF TOMATO PLANTS
}

\author{
Sahriye Sonmez ${ }^{1 *}$; Mustafa Kaplan ${ }^{1}$; Namik Kemal Sonmez ${ }^{2}$; Harun Kaya ${ }^{3}$; Ilker Uz ${ }^{4}$ \\ ${ }^{1}$ Akdeniz University - Faculty of Agriculture - Department of Soil Science \& Plant Nutrition, Antalya, Turkey. \\ ${ }_{3}^{2}$ Akdeniz University - Remote Sensing Research \& Application Center. Turkey. \\ Bati Akdeniz Agricultural Research Institute, Antalya, Turkey. \\ ${ }^{4}$ University of Florida - Soil \& Water Science Dept., Gainesville, Florida, USA. \\ *Corresponding author <ssonmez@akdeniz.edu.tr>
}

\begin{abstract}
Copper-containing fertilizers, fungicides and bactericides are extensively used in greenhouses in Turkey. Informations on effects of these applications to plants are scarce. The aim of the present study was to investigate effects of $\mathrm{Cu}$ application to a calcareous soil and to leaves on the yield and growth of tomato plants. $\mathrm{Cu}$ was first applied to soil as $\mathrm{CuSO}_{4} \cdot 5 \mathrm{H}_{2} \mathrm{O}$ in three different levels $(0,1000$, and $2000 \mathrm{mg}$ $\mathrm{Cu} \mathrm{kg}^{-1}$ ) and then to leaves in three different frequencies (no application, biweekly and weekly) using two cupric fungicides ( $\mathrm{Cu}$ oxychloride, and $\mathrm{Cu}$ salts of fatty and rosin acids) in pot experiments carried out in a computer-controlled greenhouse. Total yield, fruit number, dry root weight and plant height decreased with increasing $\mathrm{Cu}$ application to soil. Increasing levels of $\mathrm{Cu}$ applied to soil and leaves resulted in decreasing final fruit number, dry root weight and plant height in $4^{\text {th }}, 5^{\text {th }}$ and $6^{\text {th }}$ weeks. Combined applications of $\mathrm{Cu}$ to soil and leaves could be more deleterious to plants than when $\mathrm{Cu}$ is applied only to soil or leaves.

Key words: dry root weight, fruit number, fungicides, plant height, greenhouse
\end{abstract}

\section{ALTOS NÍVEIS DE COBRE NO SOLO E NAS FOLHAS REDUZ CRESCIMENTO E PRODUTIVIDADE DE TOMATEIROS}

\begin{abstract}
RESUMO: Fertilizantes, fungicidas e bactericidas cúpricos são usados em larga escala em casas de vegetação na Turquia. Informações sobre os efeitos das aplicações destes produtos sobre as plantas são escassas. Este trabalho investiga os efeitos da aplicação de $\mathrm{Cu}$ na forma de $\mathrm{CuSO}_{4} .5 \mathrm{H}_{2} \mathrm{O}$ a um solo calcário $(0,1000$ e $2000 \mathrm{mg} \mathrm{Cu} \mathrm{kg}^{-1}$ ) e em cobertura (controle, semanal e duas vezes por semana), nas formas de oxicloreto de cobre ou calda bordalesa na produção total, número de frutas, peso seco da raiz e altura de tomateiros cultivados em casa de vegetação. Produtividade total, número de frutas por planta, peso seco da raiz e altura das plantas foram reduzidas pelo aumento da quantidade de $\mathrm{Cu}$ aplicado ao solo. $\mathrm{O}$ aumento da concentração de CU no solo e folhas diminuiu número final de frutos por planta, peso seco da raiz e altura da planta na quarta, quinta e sexta semanas. A aplicação combinada de $\mathrm{Cu}$ ao solo e em cobertura pode ser mais deletéria às plantas que a aplicação de $\mathrm{Cu}$ somente ao solo ou em cobertura.

Palavras-chave: peso seco da raiz, número de futas, fungicidas, altura da planta, casas de vegetação
\end{abstract}

\section{INTRODUCTION}

Copper contents of the majority of plant species varies between 20 and $30 \mathrm{mg} \mathrm{kg}^{-1}$ dry weight. The critical copper deficiency level in vegetative plant parts is generally 3 to $5 \mathrm{mg} \mathrm{kg}^{-1}$ dry weight (Robson \& Reuther, 1981); in young grain plants it was reported to be $1.5 \mathrm{mg} \mathrm{kg}^{-1}$ dry weight (Robson et al., 1984).

Copper is an essential element for various metabolic processes. Because it is required only in trace amounts, $\mathrm{Cu}$ becomes toxic at high concentrations (Delas, 1963; Alva \& Chen, 1995). In non-tolerant plants, inhibition of root elongation and damage of root cell membranes are the immediate responses to high $\mathrm{Cu}$ levels (Wainwright \& Woolhouse, 1977). Changes in root morphology, such as inhibited elongation and enhanced lateral root formation (Savage et al., 1981), might be related to the sharp decrease in Indol Acetic Acid oxidase activity in roots exposed to high $\mathrm{Cu}$ concentrations (Coombs et al., 1976). Zheng et al. (2004) reported that excessive copper reduced plant root length, root dry weight, total dry weight, root to shoot ratio, leaf area and specific leaf area in three ornamental crops (Dendronthema $\times$ grandiflorum L. 'Fina', Rosa $\times$ hybrida L. 'Laulinger', Pelargonium $\times$ hortorum L. 'Evening Glow') grown in solution culture. 
Copper-containing fertilizers, fungicides and bactericides have been used extensively in the greenhouses in Antalya, Turkey. Kaplan (1999) reported that circa $8 \%$ of soils in Antalya contained DTPA-extractable $\mathrm{Cu}$ greater than the critical toxicity level $(20 \mathrm{mg}$ $\mathrm{kg}^{-1}$ ), and the $\mathrm{Cu}$ concentration in leaf samples was very high as a result of the intensive use of foliar applied $\mathrm{Cu}$ - containing chemicals.

Application of copper containing fertilizers, pesticides and fungicides to leaf or soil has increased gradually over the years in Mediterranean regions where soils are calcareous with neutral or alkaline $\mathrm{pH}$. It is known that $\mathrm{Cu}$ solubility decreases as soil $\mathrm{pH}$ increases. Therefore, it is thought that levels of bio-available $\mathrm{Cu}$ in the Mediterranean region are low. There are no previous reports on the effects of high levels of $\mathrm{Cu}$ containing fungicides on yield and growth of tomato plants in the Mediterranean region. The effects of $\mathrm{Cu}$ toxicity on yield and growth of tomato plants, under high levels of $\mathrm{Cu}$ applications were evaluated in this study.

\section{MATERIAL AND METHODS}

Pot experiments were conducted in a computer-controlled greenhouse located in Antalya, Turkey (30 $58^{\prime} 44^{\prime \prime E}, 36^{\circ} 55^{\prime} 49^{\prime \prime} \mathrm{N}$, altitude $\left.41 \mathrm{~m}\right)$. Pots were filled with a Xerorthent soil (Entisol) with the following chemical and physical properties: clayey textured $\left(530.4 \mathrm{~g} \mathrm{~kg}^{-1}\right.$ clay, $367.2 \mathrm{~g} \mathrm{~kg}^{-1}$ silt, and $102.4 \mathrm{~g}$ $\mathrm{kg}^{-1}$ sand); $\mathrm{pH} 6.5$ (1:2.5 soil-water ratio); $26.0 \mathrm{~g} \mathrm{~kg}^{-1}$ organic matter (Walkley-Black method); total carbonates equivalent to $44.0 \mathrm{~g} \mathrm{~kg}^{-1}$; total $\mathrm{N} 0.18 \%$; extractable P $110.80 \mathrm{mg} \mathrm{kg}^{-1}$; extractable $\mathrm{K} 241.8 \mathrm{mg} \mathrm{kg}^{-1}$; extractable Ca $2750 \mathrm{mg} \mathrm{kg}^{-1}$; extractable $\mathrm{Mg} 541.2 \mathrm{mg}$ $\mathrm{kg}^{-1}$; extractable Fe $92.35 \mathrm{mg} \mathrm{kg}^{-1}$; extractable Zn 14.80 $\mathrm{mg} \mathrm{kg}^{-1}$; and extractable $\mathrm{Cu} 15.30 \mathrm{mg} \mathrm{kg}^{-1}$. Total carbonates were determined according to the calcimeter method of Nelson (1982). Potassium, Ca and Mg were extracted with $\mathrm{NH}_{4}$-Ac and determined by atomic absorption spectrophotometry (AAS) (Kacar, 1995). Soil $\mathrm{Fe}, \mathrm{Mn}, \mathrm{Zn}$ and $\mathrm{Cu}$ were extracted with DTPA (Lindsay \& Norvell, 1978) and then determined by AAS.

Two separate experiments were carried out, each using different cupric fungicide: $\mathrm{Cu}$ oxychloride or copper salts of fatty and rosin acids. The former contains $25 \% \mathrm{Cu}$ oxychloride and is sold as a powder. The latter is a liquid fungicide containing $58 \%$ copper salts of fatty and rosin acids (CAS \# 61789-22-8), equivalent to $51.4 \mathrm{mg} \mathrm{L}^{-1}$ metallic $\mathrm{Cu}$.

\section{Experimental Design}

Twenty $\mathrm{kg}$ of air-dried soil were passed through a $4 \mathrm{~mm}$ mesh sieve and mixed with $5 \mathrm{~kg}$ of a $75 \%$ turf: $25 \%$ perlyte mixture, and distributed in 25-L pots, fertilized with mono ammonium phosphate and potassium sulphate $\left(36 \mathrm{~kg} \mathrm{~N} \mathrm{ha}^{-1}, 80 \mathrm{~kg} \mathrm{P} \mathrm{ha}^{-1}\right.$ and $112 \mathrm{~kg} \mathrm{~K} \mathrm{ha}^{-1}$ ). Copper was applied to soil at three different rates [0 (Cu1), $1000(\mathrm{Cu} 2)$ and $2000 \mathrm{mg} \mathrm{kg}^{-1}$ (Cu3)] as $\mathrm{CuSO}_{4} \cdot 5 \mathrm{H}_{2} \mathrm{O}$. One seedling of tomato (Lycopersicon esculentum (L.) Mill. Cv. F144) was planted per pot. Fungicides were applied at three different frequencies [control, no application (L1), biweekly (L2) and weekly (L3)]. The treatments were set up based on Kaplan (1999). Trials were set up in a completely randomized factorial design with nine treatments: three levels of $\mathrm{Cu}$ application to soil and three frequencies of fungicide application to leaves, in all possible combinations, $(n=4)$.

\section{Processes During and at the End of the Experiment Period}

Pots were incubated for two weeks after addition of copper and before planting. Copper application to leaves started at four weeks after planting. All pots were fertilized once a week with mono ammonium phosphate, potassium nitrate, ammonium nitrate, and magnesium sulfate. Total amounts of nutrients provided to each pot were: $195 \mathrm{~kg} \mathrm{~N} \mathrm{ha}^{-1}, 62 \mathrm{~kg} \mathrm{P} \mathrm{ha}^{-1}, 177 \mathrm{~kg} \mathrm{~K} \mathrm{ha}^{-1}$, and $16 \mathrm{~kg}$ $\mathrm{Mg} \mathrm{ha}^{-1}$. Pots also received $3.0 \mathrm{~kg} \mathrm{Fe} \mathrm{ha}^{-1}, 3.0 \mathrm{~kg} \mathrm{Mn}$ $\mathrm{ha}^{-1}, 1.13 \mathrm{~kg} \mathrm{Zn} \mathrm{ha}{ }^{-1}, 0.38 \mathrm{~kg} \mathrm{~B} \mathrm{ha}^{-1}$ and $0.08 \mathrm{~kg} \mathrm{Mo}$ $\mathrm{ha}^{-1}$.

Plant height was measured weekly from the $4^{\text {th }}$ week after planting. Fruit numbers per plant were recorded and harvested fruits were weighed. At the end of the experiment, plant roots were washed to detach soil particles, dried in a forced-air oven $\left(65^{\circ} \mathrm{C} ; 72 \mathrm{~h}\right)$, and weighed.

\section{Statistical Analysis}

Statistical analysis was carried out using the MSTAT-C software. Means were compared by analysis of variance (ANOVA) and the LSD test $(\alpha=0.05)$. A factorial analysis was used to determine interaction effects of copper application to soil and leaves on yield and growth of tomato plants.

\section{RESULTS}

\section{Experiment I (Cu Oxy Chloride Fungicide)}

Copper application to soil affected total yield, fruit number, dry root weight, and plant height $(P<$ $0.01)$. The greatest total yield, fruit number, and dry root weight were obtained when no copper was applied to soil $(\mathrm{Cu} 1)$; performance traits decreased from treatment $\mathrm{Cu} 1$ to $\mathrm{Cu} 3$ (Table 1).

Increasing the level of $\mathrm{Cu}$ application to soil resulted in decreased plant height. The greatest plant 
heights during the 11 weeks were observed when no copper was applied. On average, $\mathrm{Cu}$ application to soil resulted in 39\% and 50\% reductions in plant height in $\mathrm{Cu} 2$ and $\mathrm{Cu} 3$, respectively, in comparison with treatment $\mathrm{Cu} 1$.

Increasing levels of $\mathrm{Cu}$ application to leaves affected dry root weight and plant height after the $5^{\text {th }}$ week. The smallest dry root weight was observed in L3. Similarly, after the $5^{\text {th }}$ week, the smallest plant heights were registered for L3 (Table 2). Cu application to leaves did not affect plant height during the first four weeks. After the $5^{\text {th }}$ week, however, plant height decreased as a result of increasing levels of $\mathrm{Cu}$ application.

Table 1 - The Effects of Cu Application to Soil on Total Yield, Fruit Number, Dry Root Weight and Plant Height.

\begin{tabular}{|c|c|c|c|c|c|c|c|}
\hline \multirow{3}{*}{ Variable } & & \multicolumn{3}{|c|}{ Fungicide I } & \multicolumn{3}{|c|}{ Fungicide II } \\
\hline & & \multicolumn{3}{|c|}{$\mathrm{Cu}$ Application to Soil } & \multicolumn{3}{|c|}{$\mathrm{Cu}$ Application to Soil } \\
\hline & & $\mathrm{Cul}$ & $\mathrm{Cu} 2$ & $\mathrm{Cu} 3$ & $\mathrm{Cul}$ & $\mathrm{Cu} 2$ & $\mathrm{Cu} 3$ \\
\hline Total Yield/Plant (kg plant ${ }^{-1}$ ) & & $2.3 \mathrm{a}$ & $1.8 \mathrm{a}$ & $0.8 \mathrm{~b}$ & $2.7 \mathrm{a}$ & $1.8 \mathrm{~b}$ & $1.00 \mathrm{c}$ \\
\hline Fruit Number/Plant (fruits plant ${ }^{-1}$ ) & & $40 \mathrm{a}$ & $27 \mathrm{~b}$ & $16 \mathrm{c}$ & $40 \mathrm{a}$ & $26 \mathrm{~b}$ & $18 \mathrm{~b}$ \\
\hline \multirow[t]{6}{*}{ Dry Root Weight/Plant (g plant ${ }^{-1}$ ) } & & $8.7 \mathrm{a}$ & $4.4 \mathrm{~b}$ & $2.3 \mathrm{c}$ & $11.2 \mathrm{a}$ & $4.5 \mathrm{~b}$ & $2.9 \mathrm{c}$ \\
\hline & 1 & $17.0 \mathrm{a}$ & $13.3 \mathrm{~b}$ & $12.1 \mathrm{~b}$ & $16.2 \mathrm{a}$ & $13.4 \mathrm{~b}$ & $12.7 \mathrm{~b}$ \\
\hline & 2 & 29.6 a & $18.8 \mathrm{~b}$ & $16.3 \mathrm{~b}$ & $25.2 \mathrm{a}$ & $17.8 \mathrm{~b}$ & $16.1 \mathrm{c}$ \\
\hline & 3 & $36.7 \mathrm{a}$ & $22.3 \mathrm{~b}$ & $19.0 \mathrm{c}$ & $33.6 \mathrm{a}$ & $23.6 \mathrm{~b}$ & $17.0 \mathrm{c}$ \\
\hline & 4 & $55.4 \mathrm{a}$ & $30.2 \mathrm{~b}$ & $26.2 \mathrm{c}$ & $52.2 \mathrm{a}$ & $31.6 \mathrm{~b}$ & $27.8 \mathrm{~b}$ \\
\hline & 5 & $65.5 \mathrm{a}$ & $35.1 \mathrm{~b}$ & $29.1 \mathrm{c}$ & $62.6 \mathrm{a}$ & $36.2 \mathrm{~b}$ & $31.0 \mathrm{c}$ \\
\hline \multirow[t]{6}{*}{ Plant Height $(\mathrm{cm})$ Weeks } & 6 & 84.6 a & $44.6 \mathrm{~b}$ & $35.8 \mathrm{c}$ & 89.0 a & $44.3 \mathrm{~b}$ & $37.3 \mathrm{c}$ \\
\hline & 7 & $97.6 \mathrm{a}$ & $52.1 \mathrm{~b}$ & $41.1 \mathrm{c}$ & $102.8 \mathrm{a}$ & $50.1 \mathrm{~b}$ & $42.8 \mathrm{~b}$ \\
\hline & 8 & $110.5 \mathrm{a}$ & $62.0 \mathrm{~b}$ & $47.3 \mathrm{c}$ & $121.6 \mathrm{a}$ & $57.4 \mathrm{~b}$ & $47.3 \mathrm{~b}$ \\
\hline & 9 & $118.2 \mathrm{a}$ & $73.3 \mathrm{~b}$ & $57.5 \mathrm{c}$ & $135.5 \mathrm{a}$ & $66.3 \mathrm{~b}$ & $53.9 \mathrm{~b}$ \\
\hline & 10 & $142.3 \mathrm{a}$ & $90.8 \mathrm{~b}$ & $69.2 \mathrm{c}$ & $153.3 \mathrm{a}$ & $82.1 \mathrm{~b}$ & $64.3 \mathrm{~b}$ \\
\hline & 11 & $147.5 \mathrm{a}$ & $107.3 \mathrm{~b}$ & $82.1 \mathrm{c}$ & $163.0 \mathrm{a}$ & $96.6 \mathrm{~b}$ & $74.2 \mathrm{~b}$ \\
\hline
\end{tabular}

Means in the same row followed by the same letter are not significantly different. Fungicide I: Cu oxychloride fungicide. Fungicide II: Copper salts of fatty and rosin acids fungicide.

Table 2 - The Effects of Cu Application to Leaves on Total Yield, Fruit Number, Dry Root Weight and Plant Height.

\begin{tabular}{|c|c|c|c|c|c|c|c|}
\hline \multirow{3}{*}{ Variable } & & \multicolumn{3}{|c|}{ Fungicide I } & \multicolumn{3}{|c|}{ Fungicide II } \\
\hline & & \multicolumn{3}{|c|}{$\mathrm{Cu}$ Application to Leaves } & \multicolumn{3}{|c|}{$\mathrm{Cu}$ Application to Leaves } \\
\hline & & L1 & L2 & L3 & L1 & L2 & L3 \\
\hline Total Yield/Plant (kg plant ${ }^{-1}$ ) & & $2.0 \mathrm{a}$ & $1.5 \mathrm{a}$ & $1.5 \mathrm{a}$ & $2.1 \mathrm{a}$ & $1.6 \mathrm{a}$ & $1.7 \mathrm{a}$ \\
\hline Fruit Number/Plant (fruits plant ${ }^{-1}$ ) & & $29 \mathrm{a}$ & $26 \mathrm{a}$ & $28 \mathrm{a}$ & $29 \mathrm{a}$ & $26 \mathrm{a}$ & $28 \mathrm{a}$ \\
\hline \multirow[t]{6}{*}{ Dry Root Weight/Plant (g plant $\left.{ }^{-1}\right)$} & & $5.8 \mathrm{a}$ & $6.1 \mathrm{a}$ & $3.5 \mathrm{~b}$ & $7.5 \mathrm{a}$ & $5.6 \mathrm{~b}$ & $5.4 \mathrm{~b}$ \\
\hline & 1 & $13.7 \mathrm{a}$ & $14.9 \mathrm{a}$ & $13.8 \mathrm{a}$ & $14.9 \mathrm{a}$ & $14.2 \mathrm{a}$ & $13.3 \mathrm{a}$ \\
\hline & 2 & $21.8 \mathrm{a}$ & $20.3 \mathrm{a}$ & $19.7 \mathrm{a}$ & $20.8 \mathrm{a}$ & $19.4 \mathrm{a}$ & $18.9 \mathrm{a}$ \\
\hline & 3 & $26.4 \mathrm{a}$ & $26.4 \mathrm{a}$ & $25.2 \mathrm{a}$ & $26.2 \mathrm{a}$ & $24.6 \mathrm{a}$ & $25.4 \mathrm{a}$ \\
\hline & 4 & 38.5 a & $37.7 \mathrm{a}$ & $35.6 \mathrm{a}$ & $39.5 \mathrm{a}$ & 35.9 a & $36.1 \mathrm{a}$ \\
\hline & 5 & $46.2 \mathrm{a}$ & $43.3 \mathrm{ab}$ & $40.8 \mathrm{~b}$ & $45.5 \mathrm{a}$ & $42.0 \mathrm{a}$ & $42.3 \mathrm{a}$ \\
\hline \multirow[t]{6}{*}{ Plant Height $(\mathrm{cm})$ Weeks } & 6 & 59.7 a & 55.4 a & $49.8 \mathrm{~b}$ & $61.3 \mathrm{a}$ & $54.5 \mathrm{a}$ & $54.8 \mathrm{a}$ \\
\hline & 7 & $71.8 \mathrm{a}$ & $64.7 \mathrm{~b}$ & $54.3 \mathrm{c}$ & $71.6 \mathrm{a}$ & $62.8 \mathrm{a}$ & $61.3 \mathrm{a}$ \\
\hline & 8 & $83.1 \mathrm{a}$ & $75.3 \mathrm{a}$ & $61.4 \mathrm{~b}$ & $84.1 \mathrm{a}$ & $71.2 \mathrm{a}$ & $71.0 \mathrm{a}$ \\
\hline & 9 & $96.0 \mathrm{a}$ & $85.1 \mathrm{a}$ & $67.9 \mathrm{~b}$ & $98.0 \mathrm{a}$ & $85.1 \mathrm{a}$ & 84.9 a \\
\hline & 10 & $115.67 \mathrm{a}$ & $102.42 \mathrm{ab}$ & $84.25 \mathrm{~b}$ & $113.33 \mathrm{a}$ & $91.75 \mathrm{a}$ & $94.67 \mathrm{a}$ \\
\hline & 11 & $131.0 \mathrm{a}$ & $112.0 \mathrm{ab}$ & $93.9 \mathrm{~b}$ & $125.8 \mathrm{a}$ & $101.5 \mathrm{a}$ & $106.5 \mathrm{a}$ \\
\hline
\end{tabular}

Means in the same row followed by the same letter are not significantly different (LSD; P > 0.05). Fungicide I: Cu oxychloride Fungicide. Fungicide II: Copper salts of fatty and rosin acids Fungicide. 
The interaction between $\mathrm{Cu}$ application to soil and leaves was significant for fruit number and plant height in the $4^{\text {th }}, 5^{\text {th }}$ and $6^{\text {th }}$ week (Table 3 ). In treatment L1, in which no copper was applied to leaves, $\mathrm{Cu}$ application to soil did not change fruit number per plant, whereas in the treatments L2 and L3, fruit number decreased with increasing level of $\mathrm{Cu}$ application to soil. While the smallest fruit number in treatment L2 (11 fruits, 69.4\% decrease in comparison to the control) was recorded for treatment $\mathrm{Cu} 3$, the smallest fruit number in treatment L3 was obtained recorded for both treatments $\mathrm{Cu} 2$ and $\mathrm{Cu} 3$ (64.2\% and $75.5 \%$ decrease, respectively) (Table 3 ). Plant height in the $4^{\text {th }}, 5^{\text {th }}$ and $6^{\text {th }}$ weeks decreased from $\mathrm{Cu} 1$ to $\mathrm{Cu} 2$ when no fungicide was applied or when it was applied biweekly, while the weekly application of fungicide led to a further decrease in plant height from $\mathrm{Cu} 2$ to $\mathrm{Cu} 3$ (Table 3).

\section{Experiment II (Copper Salts of Fatty and Rosin Acids Containing Fungicide)}

Total yield, fruit number, dry root weight and plant height were affected by the level of $\mathrm{Cu}$ application to soil $(P<0.01)$. The greatest total yield, fruit number and dry root weight were obtained when no copper was applied (Table 1). As compared with treatment $\mathrm{Cu} 1$; total yield, fruit number and dry root weight decreased in the treatment $\mathrm{Cu} 2(33.5 \%, 35.0 \%$ and $60.3 \%$, respectively) and $\mathrm{Cu} 3(63.9 \%, 55.0 \%$ and $74.5 \%$, respectively). The greatest plant heights dur- ing the experiment were also obtained when no copper was applied to soil (Table 1). On average, increasing the level of $\mathrm{Cu}$ application to soil resulted in a $40.9 \%$ and $50.4 \%$ reduction in plant height in treatments $\mathrm{Cu} 2$ and $\mathrm{Cu} 3$, respectively, as compared to treatment $\mathrm{Cu} 1$.

$\mathrm{Cu}$ application to leaves resulted in a decrease in dry root weight. The greatest dry root weight was obtained in treatment L1 (Table 2). The interaction between $\mathrm{Cu}$ application to soil and leaves was significant only for dry root weight $(P<0.01)$. Copper application to soil and leaves led to a sharper decrease in dry root weight than when copper was only applied to soil (Table 3).

\section{DISCUSSION}

Successful tomato production is ordinarily associated with healthy vegetative top and root growth throughout the growing season. High levels of $\mathrm{Cu}$ application to soil and leaves seriously disrupted normal plant growth. There was an increasing reduction total yield, fruit number, dry root weight and plant height with increasing levels of $\mathrm{Cu}$ application to soil and leaves. Copper is a transition metal that participates in redox reactions. When in excess, $\mathrm{Cu}$ causes over-production of oxy radicals, which is believed to be its primary toxic effect in plant cells. Furthermore, $\mathrm{Cu}$-induced cell disturbances have consequences on main physiological processes, and impair growth

Table 3 - Significant Interactions Between $\mathrm{Cu}$ Application to Soil and Leaves.

\begin{tabular}{|c|c|c|c|c|c|c|}
\hline \multirow{2}{*}{ Fungicide } & \multirow{2}{*}{ Traits } & \multirow{2}{*}{$\begin{array}{c}\mathrm{Cu} \text { Appl. to } \\
\text { Soil }\end{array}$} & \multicolumn{4}{|c|}{$\mathrm{Cu}$ Application to Leaves } \\
\hline & & & L1 & $\mathrm{L} 2$ & L3 & Means \\
\hline & Fruit number & $\mathrm{Cu} 1$ & $33 \mathrm{a}$ & $36 \mathrm{a}$ & $53 \mathrm{a}$ & 40 \\
\hline & Fruits plant ${ }^{-1}$ & $\mathrm{Cu} 2$ & $33 \mathrm{a}$ & $30 \mathrm{a}$ & $19 \mathrm{~b}$ & 27 \\
\hline & & $\mathrm{Cu} 3$ & $23 \mathrm{a}$ & $11 \mathrm{~b}$ & $13 \mathrm{~b}$ & 16 \\
\hline & Plant Height in & $\mathrm{Cul}$ & $55.3 \mathrm{a}$ & $56.0 \mathrm{a}$ & $57.0 \mathrm{a}$ & 56.1 \\
\hline & $4^{\text {th }}$ week & $\mathrm{Cu} 2$ & $30.8 \mathrm{~b}$ & $31.0 \mathrm{~b}$ & $28.8 \mathrm{~b}$ & 30.2 \\
\hline \multirow[t]{8}{*}{ Fungicide I } & $(\mathrm{cm})$ & $\mathrm{Cu} 3$ & $31.5 \mathrm{~b}$ & $26.0 \mathrm{~b}$ & $21.0 \mathrm{c}$ & 26.2 \\
\hline & Plant Height in & $\mathrm{Cul}$ & $64.0 \mathrm{a}$ & $65.0 \mathrm{a}$ & $67.5 \mathrm{a}$ & 65.5 \\
\hline & $5^{\text {th }}$ week & $\mathrm{Cu} 2$ & $38.0 \mathrm{~b}$ & $35.0 \mathrm{~b}$ & $32.3 \mathrm{~b}$ & 35.1 \\
\hline & $(\mathrm{cm})$ & $\mathrm{Cu} 3$ & $36.5 \mathrm{~b}$ & $29.8 \mathrm{~b}$ & $22.5 \mathrm{c}$ & 29.6 \\
\hline & Plant Height in & $\mathrm{Cul}$ & $84.0 \mathrm{a}$ & $87.3 \mathrm{a}$ & $82.5 \mathrm{a}$ & 84.6 \\
\hline & $6^{\text {th }}$ week & $\mathrm{Cu} 2$ & $49.3 \mathrm{~b}$ & $43.5 \mathrm{~b}$ & $41.0 \mathrm{~b}$ & 44.6 \\
\hline & $(\mathrm{cm})$ & $\mathrm{Cu} 3$ & $45.8 \mathrm{~b}$ & $35.5 \mathrm{~b}$ & $26.0 \mathrm{c}$ & 35.8 \\
\hline & Dry Root & $\mathrm{Cu} 1$ & $14.5 \mathrm{a}$ & $9.7 \mathrm{a}$ & $9.5 \mathrm{a}$ & 11.2 \\
\hline \multirow[t]{2}{*}{ Fungicide II } & Weight & $\mathrm{Cu} 2$ & $6.0 \mathrm{~b}$ & $3.6 \mathrm{~b}$ & $3.8 \mathrm{~b}$ & 4.5 \\
\hline & $\left(\right.$ g plant $\left.^{-1}\right)$ & $\mathrm{Cu} 3$ & $2.0 \mathrm{c}$ & $3.6 \mathrm{~b}$ & $2.9 \mathrm{~b}$ & 2.9 \\
\hline
\end{tabular}

Means in the same column followed by the same letter are not significantly different at (LSD; P $>0.05)$. Fungicide I: Cu oxychloride containing Fungicide. Fungicide II: Copper salts of fatty and rosin acids containing Fungicide. 
(Marschner, 1986). Application of high levels of $\mathrm{Cu}$ usually inhibits root growth before affecting shoot production. However, this does not necessarily mean that roots are more sensitive to high copper concentrations, but probably, derives from the fact that roots are in an environment where copper is in excess (Lexmond \& Vorm, 1981).

Copper application to soil decreased total yield, fruit number, dry root weight and plant height in both experiments (Table 1). Karataglis \& Babalonas (1985) reported that plant height, shoot and root biomass, flower and fruit production decreased with increasing $\mathrm{Cu}$ concentration. Hunter (1981) reported that root growth was almost completely inhibited by $\mathrm{Cu}$ treatment in maize. Alva et al. (2000) reported 20\% reduction in root weight for 62 and $271 \mathrm{mg} \mathrm{kg}^{-1} \mathrm{Cu}$ in the roots of citrus seedlings grown in soils with $\mathrm{pH} 5.7$ and 6.5, respectively. Mazhoudi et al. (1997) reported a decline in the growth rate of tomato plants after addition of $50 \mu \mathrm{M} \mathrm{Cu}$ to a nutrient medium. Lidon \& Henriques (1992) reported that $\mathrm{Cu}$ toxicity, as expressed by reduced root length, appeared to be a direct result of the accumulation of excess $\mathrm{Cu}$ in tissues. Similarly, Rhoads et al. (1992) found that plant dry weight decreased with increasing $\mathrm{Cu}$ level in 'Florida 502' oats. Lombardini \& Sebastiani (2005) registered that Prunus cerasifera plantlets grown in vitro had smaller growth rate (for both fresh and dry weight) at $100 \mathrm{~m} \mu \mathrm{M}$ of copper.

$\mathrm{Cu}$ application to leaves affected dry weight of roots in both experiments. Plant height after the $5^{\text {th }}$ week was also affected by foliar application of the $\mathrm{Cu}$ oxy chloride fungicide, but not by the copper salts of fatty and rosin acids fungicide (Table 2). Reasons for these differences are unknown. However, there are other reports of excessive $\mathrm{Cu}^{+2}$ depressing root (Hill et al., 2000; Lidon \& Henriques, 1992; Ouzounidou, 1994) and shoot growth in other plants (Lin et al., 2003; Maksymiec \& Baszynski, 1996).

While the interaction between $\mathrm{Cu}$ application to soil and leaves was found to be significant for fruit number and plant height in the $4^{\text {th }}, 5^{\text {th }}$ and $6^{\text {th }}$ week, when $\mathrm{Cu}$ oxychloride-containing fungicide was used, it was significant only for dry root weight when copper salts of fatty and rosin acids-containing fungicide was used (Table 3). Copper application to soil and leaves resulted in a sharper decrease in dry root weight, fruit number, and plant height in the $4^{\text {th }}, 5^{\text {th }}$ and $6^{\text {th }}$ week than when copper was only applied to soil. High levels of $\mathrm{Cu}$ application to soil and leaves to control plant diseases, can negatively affect yield and growth of tomato plants. The combined application of $\mathrm{Cu}$ to soil and leaves could be more deleterious to plants than when $\mathrm{Cu}$ is applied only to soil or leaves.

\section{ACKNOWLEDGEMENTS}

The Scientific Studies Management Unit of Akdeniz University provided financial support for this project. Authors also would like to acknowledge The Batý Akdeniz Agricultural Research Institute in Antalya for its contribution.

\section{REFERENCES}

ALVA, A.K.; CHEN, Q. Effects of external copper concentrations on uptake of trace elements by citrus seedlings. Soil Science, v.159, p.59-64, 1995.

ALVA, A.K.; HUANG, B.; PARAMASTUAM, S. Soil pH affects copper fractionation and phytotoxicity. Soil Science Society of America Journal, v.64, p.955-962, 2000.

COOMBS, A.J.; LEEP, N.W.; PHIPPS, D.A. The effects of copper on IAA-Oxidase activity in root tissue of barley (Hordeum vulgare, cv. Zephyr). Zeitschrift fur Pflanzenphysiologie, v.80, p.236-242, 1976.

DELAS, J. The toxicity of copper accumulated in soils. Agrochemica, v.7, p.258-288, 1963.

HILL, S.S.; MIYASAKA, S.C.; YOST, R.S. Taro responses to excess copper in solution culture. Hortscience, v.35, p.863-867, 2000.

HUNTER, R.B. A reversible phase of copper toxicity in maize roots. Journal of Plant Nutrition, v.3, p.375-386, 1981.

KACAR, B. Chemical analyses of plant and soil. III. Soil analyses. Ankara: Ankara University Press, Agriculture Faculty, 1995. p.255307.

KAPLAN, M. Accumulation of copper in soils and leaves of tomato plants in greenhouses in Turkey. Journal of Plant Nutrition, v.22, p.237-244, 1999.

KARATAGLIS, S.; BABALONAS, D. The toxic effects of copper on the growth of Solanum lycopersicum $\mathrm{L}$. collected from $\mathrm{Zn}$ and $\mathrm{Pb}-$ soil. Angewandte Botanik, v.59, p.45-52, 1985.

LIDON, F.C.; HENRIQUES, F.S. Copper toxicity in rice: Diagnostic criteria and effect on tissue Mn and Fe. Soil Science, v.154, p.130135,1992

LIN, L.X.; LIANG, W.S.; LIU, D.H. Accumulation of copper by roots, hypocotyls, cotyledons and leaves of sunflower (Helianthus annuus L.). Bioresource Technology, v.86, p.151-155, 2003.

LINDSAY, W.L.; NORVELL, W.A. Development of DTPA soil test for zinc, iron, manganese and copper. Soil Science Society of America Proceedings, v.42, p.421-428, 1978.

LEXMOND, T.M.; VORM, P.D.J.VAN DER. The effect of $\mathrm{pH}$ on copper toxicity to hydroponically grown maize. Netherlands Journal of Agricultural Science, v.29, p.217-238, 1981.

LOMBARDINI, L.; SEBASTIANI, L. Copper toxicity in Prunus cerasifera: growth and antioxidant enzymes responses of in vitro grown plants. Plant Science, v.168, p.797-802, 2005.

MARSCHNER, H. Mineral nutrition in higher plants. Orlando: Academic Press, 1986. p.287-300.

MAKSYMIEC, W.; BASZYNSKI, T. Different susceptibility of runner bean plants to excess copper as a function of the growth stages of primary leaves. Journal of Plant Physiology, v.149, p.217-221, 1996.

MAZHOUDI, S.; CHAOUI, A.; GHORBAL, N.H.; EL-FERJANI, E. Response of antioxidant enzymes to excess copper in tomato (Lycorpersicon esculentum, Mill.). Plant Science Limerick, v.127, p.129-137, 1997.

NELSON, R.E. Carbonate and gypsum. In: PAGE, A.L.; MILLER, R.H.; KEENEY, D.R. (Ed.). Methods of soil analysis. Madison: SSSA, 1982. p.181-197.

OUZOUNIDOU, G. Root growth and pigment composition in relationship to element uptake in Silene compacta plants treated with copper. Journal of Plant Nutrition, v.17, p.933-943, 1994.

RHOADS, F.M.; BARNET, R.D.; OLSON, S.M. Copper toxicity and phosphorus concentration in Florida SO2 oats. Proceedings of the Soil and Crop Science Society of Florida, v.51, p.18-20, 1992. 
ROBSON, A.D.; REUTHER, D.J. Diagnosis of copper deficiency and toxicity. In: LONERAGAN, J.F.; ROBSON, A.D.; GRAHAM, R.D. (Ed.). Copper in soils and plants. Orlando: Academic Press, 1981. p.287-312.

ROBSON, A.D.; LONERAGAN, J.F.; GARTRELL, J.W.; NOWBALL, K. Diagnosis of copper deficiency in wheat (Triticum aestivum cultivar Gamenya) by plant analysis. Australian Journal of Agricultural Research, v.35, p.347-358, 1984.

SAVAGE, W.; BERRY, W.L.; REED, C.A. Effects of trace element stress on the morphology of developing seedlings of lettuce (Lactuca sativa L. Grand Rapids) as shown by scanning electron microscopy. Journal of Plant Nutrition, v.3, p.129-138, 1981.
WAINWRIGHT, S.J.; WOOLHOUSE, H.W. Some physiological aspects of copper and zinc tolerance in Agrostis tenuis Sibth: Cell elongation and membrane damage. Journal of Experimental Botany, v.28, p.1029-1036, 1977.

ZHENG, Y.B.; WANG, L.P.; DIXON, M.A. Response to copper toxicity for three ornamental crops in solution culture. Hortscience, v.39, p.1116-1120, 2004.

Received June 27, 2005

Accepted April 12, 2006 